\title{
Sexually transmitted papillomavirus infections: epidemiology, pathogenesis, clinic, morphology, important differential diagnostic aspects, current diagnostic and treatment options
}

\author{
Infecções por papilomavírus sexualmente transmitida: epidemiologia, \\ patogênese, clínica, morfologia, aspectos importantes do diagnóstico \\ diferencial, diagnóstico atual e opções de tratamento
}

\author{
Georgi Tchernev ${ }^{1}$
}

\begin{abstract}
The family of human papilloma viruses (HPV) comprises more than 100 genotypes. Approximately 30 of the genotypes are responsible for infections in the human anogenital area. A precisely defined algorithm with the goal of diagnosing and removing HPV for a prolonged or indefinite length of time, as well as to protect the patient from any malignant transformation, does not currently exist. The identification of HPV strains by PCR or DNA hybridization in lesional tissue provides higher security for the patients. In high-risk patients additional colposcopy, rectoscopy, and urethroscopy/cystoscopy increase the probability of proper diagnosis and the application of a reliable therapeutic strategy.

Removal of lesions by means of invasive methods, such as electrodessication, cryosurgery, and/or laser therapy, may be successful and could be combined pre- and postoperatively with the local application of podophyllotoxin, Trichloroacetic acid, 5-fluorouracil epinephrine gel, imiquimod, cidofovir or interferon. The administration of vaccine to young patients prevents to a significant extent the clinical manifestation of the most frequent viral strains, being HPV-6,-11 and -18. The different therapeutic methods must be applied in accordance with the clinical picture, taking into account the patient's general status, the presence of concomitant diseases, as well as the local and systematic compatibility of the side effects of each remedy.

The review focuses on the diagnosis and treatment options of sexually transmitted HPV-infections and includes synopsis of the most recent literature regarding new data of epidemiology, pathogenesis, differential diagnosis and morphology of HPV infections in humans.
\end{abstract}

Keywords: Bowen's disease; Interferons; Papilloma

Resumo: A família de papiloma vírus humano (HPV) compreende mais de 100 genótipos. Aproximadamente 30 dos genótipos são responsáveis pelas infecções na área anogenital em humanos. Não dispomos no momento de um algoritmo precisamente definido tendo como meta o diagnóstico e a remoção de HPV por períodos de tempo prolongados ou indefinidos, nem para proteção do paciente contra transformação maligna. A identificação das cepas de HPV por PCR ou hibridização de DNA em tecido lesional oferece maior segurança para os pacientes. Em pacientes de alto risco realiza-se ainda colposcopia, rectoscopia e uretroscopia/ cistoscopia, aumentando a probabilidade do diagnóstico correto e a aplicação de estratégia terapêutica confiável. A remoção das lesões por meio de métodos invasivos, como a eletrodissecção, criocirurgia, e/ou terapia com laser, pode ser bem sucedida e combinada no pré e no pós-operatório com a aplicação local de toxina podofílica, ácido tricloroacético, gel de epinefrina 5-fluorouracil, imiquimod, cidofovir ou interferon. A administração da vacina em pacientes jovens é capaz de previnir as manifestações clínicas das cepas virais mais frequentes, que são HPV-6, -11 e -18. Os diferentes métodos terapêuticos devem ser aplicados de acordo com o quadro clínico, levando em consideração o estado de saúde geral do paciente, a presença de doenças concomitantes, assim como a compatibilidade local e sistêmica dos efeitos adversos em cada remédio. A revisão foca o diagnóstico e as opções de tratamento de infecções por HPV sexualmente transmitidas e inclui uma sinopse da literatura mais recente no que diz respeito aos dados de epidemiologia, patogênese, diagnóstico diferencial e morfologia de infecções por HPV em humanos.

Palavras-chave: Doença de Bowen; Interferons; Papiloma

\footnotetext{
Aprovado pelo Conselho Editorial e aceito para publicação em 27.01.09.

* Study carried out at Department of Dermatology, Venereology and Dermatosurgery VOP/MVZ Kirchheim, Germany. Conflict of interest: None /Conflito de interesse: Nenhum.

Financial Funding: None/ Suporte financeiro: Nenhum.

MD, PhD. Department of Dermatology, Venereology and Dermatosurgery VOP/MVZ Kirchheim, Germany.
} 


\section{INTRODUCTION}

The number of new human papilloma virus (HPV)-associated infections in the anogenital area has reached 1 million cases per year, whereas the number of female patients prevails. ${ }^{1}$

HPV primarily infect the epithelial cells of the skin and mucous membranes. Infection rates vary, and depend on the quantity of virus particles, the type, intensity, and length of contact, and also on the patient's immunity status. ${ }^{2}$

The family of HPV comprises more than 100 genotypes. Approximately 30 of the genotypes are responsible for infections in the anogenital area. Visible anogenital warts are induced by HPV-6 and $\mathbf{- 1 1}$ strains. 3 Mixed infections, i.e., the presence of various oncogenic types of papilloma viruses within a lesion, is quite common. ${ }^{4}$ The HPV-16, -18, -31, -33, and -35 types are regularly found in the pre-stages of cervical carcinoma 4 and necessitate surgical excision, as well as an adjuvant, stage-oriented local/systemic therapy. Patients suffering from Bowen's disease, bowenoid papulosis, and Queyrat's erythroplasia present HPV16-associated intraepithelial neoplasia. ${ }^{4}$

Among the most frequent genital HPV-associated lesions are condylomata acuminata subtypes HPV6, -11, -42, $-44,-51,-55$, and $-69 .{ }^{5}$ Subtypes HPV-6, -11 $-16,-18,-33,-35,-39,-45,-51,-52,-54,-56$, and -66 are found in the anogenital carcinomas. In the case of in situ carcinomas, the strains HPV-6, -11, -16, -18, -30, $35,-39,-40,-42,-43,-45,-51,-52,-56,-57,-59,-61,-$ 62 , and -64 are found. ${ }^{5}$

Partial HPV sequences, identified in material acquired from biopsied lesions, prove the presence of more than $50 \mathrm{HPV}$ subtypes. The unusual diversity of papilloma viral strains is probably due to evolutionary processes of millions of years. ${ }^{2}$

The observation of certain diagnostic algorithms at the time of initial diagnosis leads to the strict elucidation of a lesion's identity and helps us in the choice of the proper therapeutic protocol.

\section{EPIDEMIOLOGY}

Generally, papilloma virus-associated infections are very frequent and occur not only in 20 to 40 -old patients, but also in children and teenagers. ${ }^{2,5}$ In the case of immuno-incompetent patients (e.g., HIV infection and post-organ transplantation), the frequency of infections and the clinical manifestations of sub-clinical and latent lesions can increase significantly. ${ }^{2}$ The transmission of infection to the anogenital area takes place mainly from human-to-human and animal-tohuman. 2,5

Autoinoculation can also frequently cause multiple manifestations of HPV-associated lesions in the anogenital area.
Clinical cases in which disseminated anogenital lesions are observed are also frequent. Depending on their localization and trend to grow, the virally-induced HPV lesions can lead to many complications. The subcutaneous connective tissue in the genital and perigenital area of men and women is crumbly and well vascularized, and the quantity of collagen filaments is reduced. This is what contributes to the fast development of infection and edema, which can later affect even deeper compartments. This way, in presence of poor hygiene during the postoperative period, the development of erysipelas, soft tissue, thromboses and lymphatic edema is favored.

About $1 \%$ of the sexually active individuals in the US and Europe between 15 and 45 years of age have anogenital warts, most frequently those affected are between 20 and 25 years of age. ${ }^{6-8}$ The HPV infections are, together with chlamydia and herpes simplex virus infections, some of the most frequent sexuallytransmitted diseases. ${ }^{9}$

From an epidemiologic point of view, the number of sexual partners and the presence of recrudescent chlamydia infections are the most important factors for the clinical manifestations of anogenital warts. 10 Some of the most recent bibliographic data are disputing the first factor, as they showed that a change of partners is not always a risk factor of papilloma virus infections. ${ }^{11}$

Generally, the infection is sexually transmitted. Nevertheless, the possibility of contamination by a highly transmissible material of the anogenital area in the respective predisposed groups must not be excluded. ${ }^{3}$ Female labia minora and labia majora, the vulva, vagina and cervix, as well as the prepuce and the perigenital area of men are the most frequently areas affected. Besides the heterosexual way of sexual transmission, the homosexual transmission is also possible. In this collective of patients, HPV lesions can also be observed in the perianal area and not rarely in the anal canal, too.

The infection may be transmitted during childbirth to the newborn and this may subsequently cause laryngeal papillomatosis. ${ }^{12}$ The clinical manifestation of anogenital warts of newborns of several months of age is an alarming sign and should alert parents and healthcare providers about possible sexual abuse, which according to some authors, accounts for up to $43 \%$ of cases. ${ }^{12,13}$ The incubation period of this infection lasts from 3 weeks to 8 months or years. ${ }^{2,14,15}$ The presence of high-risk papilloma strains, such as HPV-16 or -18 in Bowen's disease, Querat's erythroplasia, as well as in bowenoid papulosis, undoubtedly shows the malignant potential of the papilloma viruses. ${ }^{16-19}$ 


\section{PATHOGENESIS}

Minor wounds in the anogenital region caused during intercourse favor invasion by papilloma viruses into the basal layer of the epidermis. ${ }^{2}$ The activation of certain viral proteins after a specific latent period leads to intensified proliferative activity of the affected cells. The integration of viral proteins in human cells disturbs cellular homeostasis. The expression of E6 and $\mathrm{E} 7$ genes leads to immortalization of keratinocytes and stimulates cellular proliferation. ${ }^{2}$ Simultaneously, cellular differentiation and aging are stopped or retarded. The different association of certain clinical lesions with certain papilloma viral strains (e.g., condylomata acuminata with HPV-6 and -11, or HPV-16 and -18 with cervical carcinomas), correlates to some extent with the different activities of E6 and E7 gene products, which, are oncogenic. ${ }^{2}$ The more the differentiation processes in the affected keratinocytes progresses, the more the expression of the viral proteins is strengthened, and they consequently form the viral particle. The cellular nuclei of the above keratinizing epidermal layer contain highly concentrated viral particles which, upon separating from the tissue, are highly infectious. It is not clear to what extent external factors play an auxiliary role in the clinical manifestation of certain HPV associated lesions.

The presence of immune defects in certain groups of patients is able to favour the early clinical manifestation, the infiltrative proliferating growth, and, in the cancer-inducing strains, to potentate the malignant transformation of the lesions. ${ }^{2}$

\section{Clinical Features, Morphology, and Localization}

Clinical localization of the anogenital HPV-associated lesions may be variable and the most predisposed places are the genital and adjacent areas. ${ }^{2,5}$ It is difficult to discern any difference between benign and malignant lesions during the course of an initial clinical examination, so a detailed histological and cytologic analysis is needed.

Non-circumcised, HPV-infected men have warts located on the glans penis and sulcus coronarius areas (Figure 1a). ${ }^{20}$ Manifestations on the scrotal, inguinal, and perianal areas are not as frequent (Figures 1b, 1c, and 1d). ${ }^{21-23}$ Bowen's disease and Queyrat's erythoplasia are the most severe forms of neoplastic alterations in the area of the genitoanal interstitial mucosa. It is not always possible to discriminate them from bowenoid papulosis. ${ }^{24}$ Men present a higher frequency of intra-urethral warts and every fourth patient having external genital warts also exhibits intra-urethral infection. ${ }^{21}$ In most cases the cutaneous clinical manifestation of genitoanal warts is multi-focal (Figure 1a, 1b). In cases of multiple lesions, an immune defect or diabetes mellitus may be present. ${ }^{15,25}$ Not only classi- cally exophytic, but partially local destructive growth, is characteristic for some of the HPV-associated lesions (Figures 1d, 2d, 2e, and 2f). ${ }^{24}$

At initial dermatologic examination, lesions frequently show a superficial plaque-like growth and their exophytic nature is not completely expressed. With progressive stages, such as giant condylomas of the Buschke Löwenstein type, infiltrated tumor growth is observed. However, a clinically small lesion may show both infiltrated endophytic and exophytic growth. To a significant extent, this phenomenon is not determined by the size but the kind of papilloma viruses in the growth, by the patient's immune status, and the anatomic location of the lesion itself. ${ }^{2}$ As a lesion cannot be clinically determined to be benign or malignant, a dermatologist must follow a specific algorithm for the purpose of elucidating the lesion's identity.

By secondarily generated bacterial infection during the postoperative period, serious preconditions for the dissemination of the infection to deeper compartments of both anal and perianal areas are created and, simultaneously, the risk of thrombosis and sepsis is quite real. The lesional morphologic structure does, indeed, not support prognosis. Although both Queyrat's erythoplasia and Bowen's disease show a trend to plaque-like endophytic growth, frequently exophytic papilloma-virus-associated lesions contain analogous oncogenic strains.

\section{Differential diagnosis}

Some benign diseases, such as fibromata pendulantia, dermal congenital naevi, seborrhoeic keratoses, pearly penile papules, but also some malignant skin diseases, such as malignant melanoma, plane-cellular carcinoma, and Bowen's carcinoma must be taken into account and bowenoid papulosis must not be overlooked either. ${ }^{20,21}$ Condylomata lata within secondary syphilis must be obligatorily excluded.

\section{Diagnostic Procedure}

The most important initial step to determine the type of lesion is the clinical dermatologic examination. Using a magnifying glass, vascular formations in the form of dots can be seen. Due to the extraordinarily difficult interpretation of the intensity of color and the risk of false positive results (e.g. erosions, inflammation with Candida albicans, genital forms of eczema, lichen ruber planus, lichen sclerosus et atrophicus, psoriasis, or genital herpes), the interpretation of data is complex and not always possible.

In case of a doubt about virally induced papilloma lesion, the application of 3-5\% (3\% for mucous membranes/ and 5\% for vulva, perigenital area) acetic 

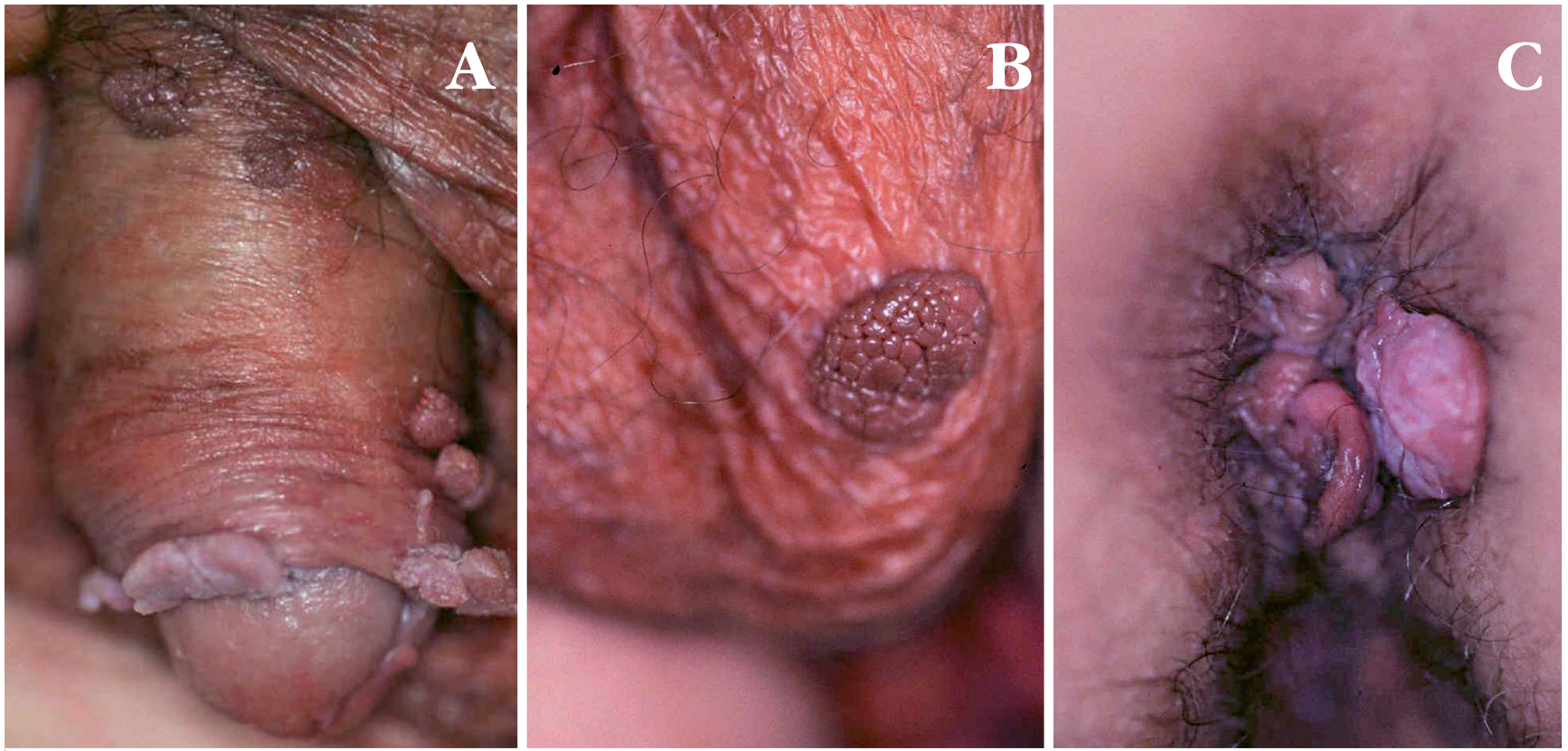

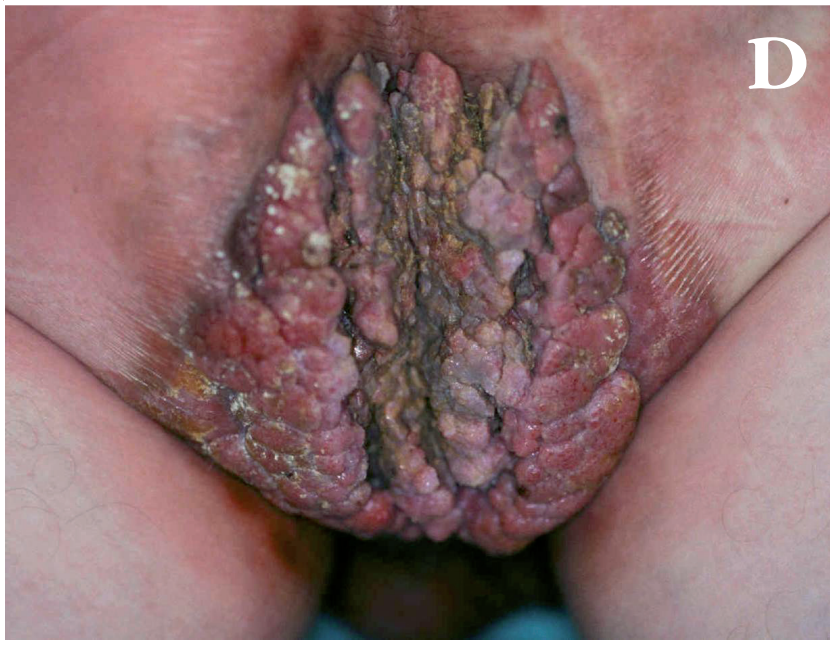

acid into the area of the vagina, the cervix and the anal canal by means of gauze sponge or compress is able in about 5 minutes to help with the initial differentiation of the neoplastic lesion, due to the generated contrast phenomena. Further cytologic and/or histologic preparations should be undertaken.

The histological picture frequently shows epidermal dilatation, i.e. acanthosis and papillomatosis. In the superior part of the stratum granulosum and stratum spinosum, large, vacuolized cells with nuclear basophilic particles can be found. ${ }^{5}$ Hyperkeratosis accompanied by parakeratosic formations can be found in the epidermis. Due to the fact that anogenital warts induce histopathologic alterations in the form of the so-called koilocytes, the histological/cytologic specimen is the first step of primary importance to prove the diagnosis (Figures $2 \mathrm{a}, 2 \mathrm{~b}$, and $2 \mathrm{c}$ ). ${ }^{20,21}$
FIGURE 1: A. A patient with exophytic genital condyloma acuminatum (HPV-6 and -11 positive). Presence of bowenoid papulosis in the form of endophytically growing plaque-like tumors with brown color in the base of the penis: types HPV-16, -18 , or $-31(+)$;

B. Initial form of Buschke Löwenstein tumor in the scrotal area in HIV-positive homosexual patient;

C. Verrucous carcinoma with perianal location in 48 years old HIV negative female patient: thickness of the tumor $6.5 \mathrm{~mm}$, HPV-6, and $-11(+)$;

D. Perianal tumor of Buschke Löwenstein with strongly expressed infiltrating growth

The histology of a number of macular lesions or anogenital lesions growing in an endophytic manner is often shown to be intra-epithelial cervical neoplasia, anal neoplasia and neoplasia of the vulva; to determine their exact stage, staining according to Papanicolaou and PAN must be made. The specific stain of certain antigens by immunohistochemistry (i.e. PAN) proves the presence or absence of papilloma viruses in the sample and determines the further diagnostic steps of the physician-in-charge. ${ }^{4}$ The positive finding in PAN-staining must be obligatorily accompanied by an exact determination of the type of the virus strains. ${ }^{4,15,26}$

Direct immunofluorescence is successfully applied to decode group-specific antigens in highly differentiated cells having a highly concentrated viral 
content. $^{2}$ Due to its low sensibility and specificity its application is limited.

PCR performed with the help of specific PCR group-specific probes is a highly sensitive and promising method finding wider application in modern dermatology clinics. This method helps to prove the presence of even the smallest quantities of papilloma viruses in the cells. ${ }^{2}$

DNA hybridization of histological tissues by means of both radioactive and non-radioactive techniques can be performed on cryostatic excerpts and formalinized excerpts of HPV-infected cells. Due to the fact that this technique is not suitable for the detection of high-risk, malignant HPV strains and is also time and labor intensive, with a sensitivity which is similar to PCR methods, its application is limited. ${ }^{2,5}$

The application of electronic microscopy can demonstrate parts of a papilloma virus in the case of "fresh" lesions. ${ }^{2}$ The presence of elementary HPV particles located in cuboidal cells on the superior part of stratum spinosum and stratum granulosum is characteristic. These particles are crystalloid aggregates and can be diffusely located in chains and/or groups. Routine application of electronic microscopy in the initial diagnosis is not considered as a standard at this time. ${ }^{2}$

Commercial serological tests are able to define a limited number of genotypes of papilloma strains and this restricts their routine application. ${ }^{2}$

Additional colpo- urethro-, cysto- and rectoscopy are recommended to be applied to patients at risk. The discovery and removal of any asymptomatic foci located in these areas prevents more serious complications in case of further destructive tumor growth. The development of genital and anal carcinomas on the basis of long-persisting venereal warts is considered to be rare. More often, these cases involve verrucous carcinomas, which are HPV-6 and -11 positive (Figures 1c, 2a, 2b, and 2c). Cervical carcinoma, as well as penile and vulvar carcinomas are considered to have originated on the basis of pre-malignant neoplastic lesions, known as CIN (cervical intraepithelial neoplasia), AIN (anal intraepithelial neoplasia), VIN (vulvar intraepithelial neoplasia), and PIN (penile intraepithelial neoplasia) (Figure 1a). ${ }^{16,17}$ By definition, bowenoid papulosis represents a severe form of penile, perianal, and vulvar neoplasia (VIN-3, PIN-3, and PAIN-3).

About one-fourth part of women with anogenital warts present with similar vaginal and/or cervical alterations, and this makes colposcopy (vaginoscopy) inevitable. ${ }^{27}$ Bearing in mind that cervical carcinoma is considered and recorded as a sexually transmitted disease, according to the World Health Organization, the determination of cervical or vaginal intra-epithelial neoplasia (VAIN/CIN) and the application of the respective therapeutic concepts according to the location and dimensions of the lesions is of paramount importance for the patient's prognosis. ${ }^{28,29}$

\section{Non-invasive therapeutic Methods \\ Podophyllotoxin}

Podophyllotoxin $(0.5$ and $0.15 \%)$, in the form of solution or an ointment, is an easily applicable method providing good results. ${ }^{30}$ The substance represents a purified extract from the podophyllon plant and has the property to combine with cellular microtubules, blocking mitosis, which is in the root of the formation of necrosis in the wart itself. ${ }^{30}$ After the removal of the wart, erosive alterations frequently remain, which heal within 3 to 4 weeks. ${ }^{4}$ The therapeutic cycle with podophyllin solution or ointment consists of the application twice daily for 3 consecutive days followed by a 4- to 7-day medication intermission. Podophyllotoxin (0.5\%) in the form of a solution is frequently applied to the male patient with anogenital warts, while the podophyllontoxin in the form of an ointment $(0.15 \%)$ is more often used in the cases of intra- or perianally located warts, as well as in cases of warts of the vulva. ${ }^{30}$

Clinical research has shown that 1 to 2 cycles with $0.5 \%$ podophylontoxin in the form of a solution is sufficient to eliminate anogenital warts in $70-90 \%$ of the cases of non-circumcised men. Between 1 and 4 cycles are necessary for the complete elimination of the warts located on the penis. 30 Side effects, in the form of erythema and erosions, are noticed during the initial application in 50-65\% of male patients. ${ }^{4,31}$ The application of $0.5 \%$ podophyllotoxin in the form of a solution to women and circumcised men is a pending question, because it does not lead to the expected results. Durable effects are achieved in less than $50 \%$ of the patients. ${ }^{31}$ The advantage of the $15 \%$ podophyllontoxin in the form of an ointment applied to venereal warts located on the vulva and the anus is evident, but not quite clarified yet. Patients having venereal warts located in these areas achieve durable remissions in some authors' opinions after 1 to 4 cycles in $60-80 \%$ of the cases. ${ }^{4}$ Recurrences according to the different forms of the preparation described are found in $7-38 \%$ of cases. ${ }^{4}$ In case that no therapeutic effect is achieved after 4 cycles, an alternative method is generally applied. Intraurethral warts located in the meatus urethrae can be refractory to this preparation. ${ }^{4}$ Therapy with podophyllontoxin is currently substituted by more advanced therapeutic agents, such as interferon BETA and imiquimod. ${ }^{4}$

A randomized comparison with once weekly podophyllin shows initial complete clearance of 93 percent versus 77 percent for surgical excision, and 

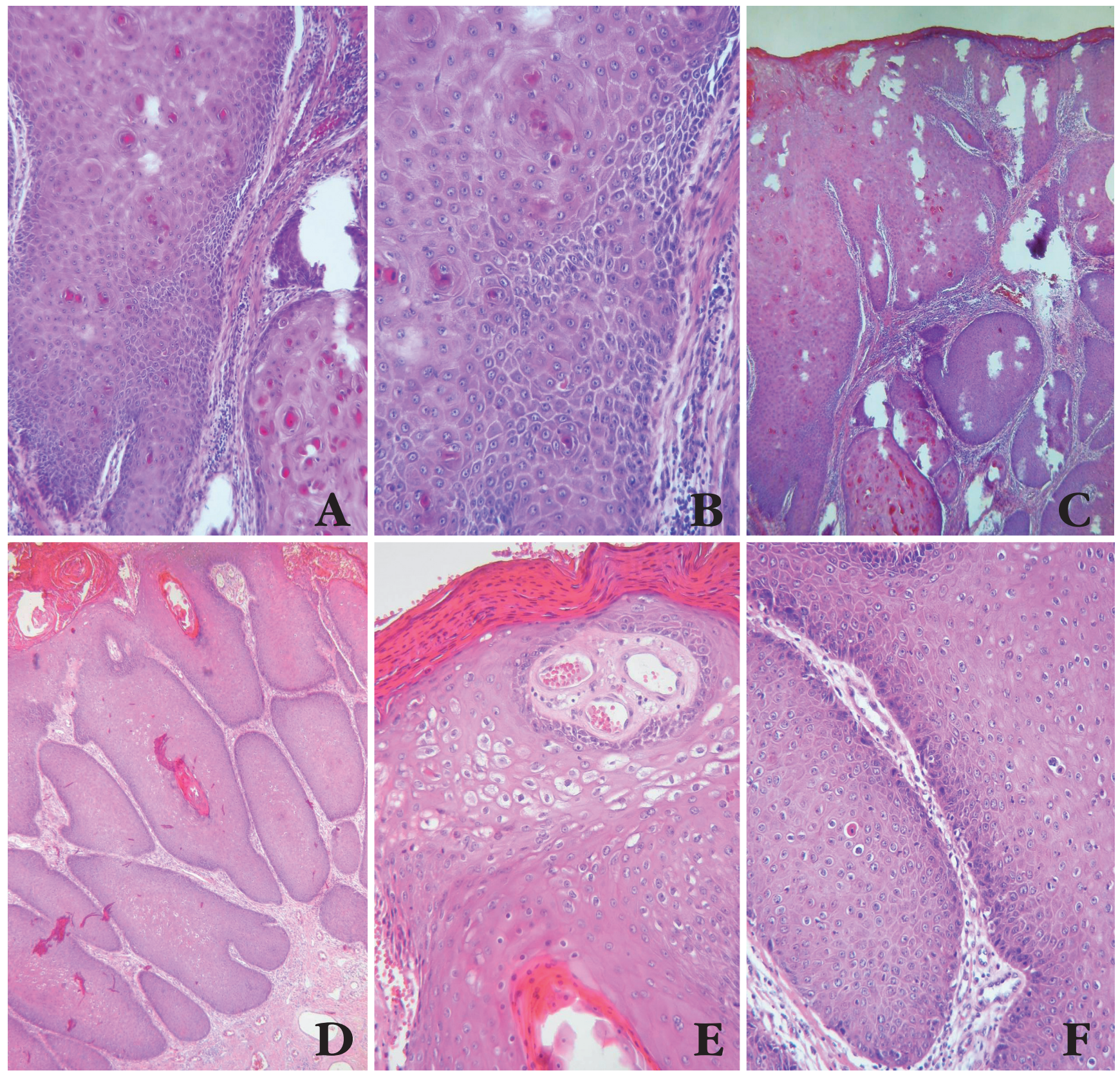

Figures 2: A (100x), B (200x), C (40x). Highly differentiated verrucous plane cellular tumor of the perianal area;

D (40x), E (200), F (200). Papillar verrucous highly differentiated carcinoma with big conglomerates of polymorphic tumor cells (2d, 2f)

recurrence rates at 6 months of 22 percent versus 56 percent for excision. ${ }^{32}$ When compared individually with podophyllotoxin, cryotherapy, and electrosurgery, or when used with intralesional interferon as an adjuvantt therapy, podophyllin alone appears less effective. Recurrences are reported for 23-65 percent of clinical trial participants. The use of podophyllin is contraindicated in pregnancy.

Some authors report a randomized trial in 358 subjects comparing clinic-applied podophyllin with patient-applied podophyllotoxin solution and cream.
Self-applied podophyllotoxin solution is three times more likely to be associated with short term cure than podophyllin, and podophyllotoxin cream is twice as likely. ${ }^{33}$ Both podophyllotoxin preparations are also more cost-effective than podophyllin. Podophyllotoxin solution could be used for penile lesions; cream or gel formulations are easier to use for anogenital and vaginal lesions. ${ }^{34}$ Although data suggest that it is safer than podophyllin, podophyllotoxin is contraindicated during pregnancy. 


\section{Trichloroacetic acid}

The application Trichloroacetic acid in concentrations up to 90 percent is also possible as a treatment option. This agent destroys genital wart on contact. It is applied directly to the warts with a cotton tip applicator each week for 3-4 consecutive weeks. Trichloroacetic acid is suitable for small warts only. The acid is associated with local burning that is immediate and lasts for a few minutes. Usually patients need repeat sessions to clear genital warts. Unlike podophyllin, TCA can also destroy vaginal warts.

\section{5- Fluorouracil epinephrine Gel}

5-FU prevents HPV DNA synthesis, which causes the cells that form genital warts to die. 5-FU is available as a 5\% cream applied topically to the warts for five to seven days and is washed off 3 to 10 hours after it is applied. 5-FU can be used to treat intravaginal warts. The recurrence rate for fluorouracil is about $\mathbf{5 0}$ percent after three months.

\section{Imiquimod}

Imiquimod was introduced for the treatment of anogenital warts in $1997 .{ }^{32}$ Its principal effect consists of the activation of congenital and acquired T-cell immunity and its further antitumor, antiviral and immunomodulatory effects. ${ }^{35}$ Imiquimod is applied topically in the form of a 5\% imiquimod ointment. The nucleoside-like substance induces the secretion of interferon- $\alpha$ and other important pro-inflammatory cytokines. ${ }^{35,36}$ In cultivated human keratinocytes, the synthesis and secretion of interferon- $\alpha$, interleukin (IL)-6, and IL-8 is induced. Peripheral macrophages are stimulated to produce interferon- $\alpha$, tumor necrosis factor- $\alpha$, IL-1, IL-6, IL-8, IL-10 and granulocyte macrophage colony-stimulating factor (GM-CSF). ${ }^{33}$ The local application of imiquimod leads to regression of the anogenital warts and reduction of the HPVDNA. ${ }^{4}$ The so-called bowenoid papulosis also shows good results. Treatment must be repeated and patients place the substance directly on the warts. After 8-10 hours they wash it out with tepid water and soap. It is recommended that this procedure be regularly repeated during 16 weeks. ${ }^{37,38}$ Side effects, like erosions and erythema, are not rare during the initial phase of the therapy. ${ }^{37}$ The average period necessary to observe a regression of anogenital warts in female patients is much shorter ( 8 weeks) than in male patients (12 weeks). ${ }^{35}$ According to some authors, in certain samples of patients, the 3-time weekly application during 4 weeks provides similar results of convalescence (40\%) compared to the 16-week application (51.6\%). ${ }^{38}$ Other authors define the susceptibility to development of recurrences after a course of 3 and 6month therapy as similar. ${ }^{39}$ The results in patients treated with $5 \%$ imiquimod and $0.5 \%$ podophilic toxin were similar. ${ }^{40}$ One of the advantages of the $5 \%$ imiquimod seems to be its better local compatibility. ${ }^{40}$

In randomized placebo-controlled trials, 5 percent imiquimod cream shows clearance within 16 weeks of up to 50 percent of warts. ${ }^{41,42}$

\section{Cidofovir}

Cidofovir is an acyclic nucleoside phosphonate with a wide-range antiviral effect with respect to some HPV-induced tumors. ${ }^{43-45}$ This substance can be locally placed in the form of $1 \%$ or $3-5 \%$ gel or ointment, as well as administered intravenously. ${ }^{43,44}$ The substance can provoke programmed cell death among the cells of the tumor population. ${ }^{27}$ This preparation also gave good results applied to the inguinal area of a 3-yearold patient. ${ }^{46}$ The topical single perianal use of $1 \%$ cidofovir within 14 days in the form of an ointment in HIV-positive patients led to full remission and absence of any recurrences of warts during the next 14 months. ${ }^{47}$ Cidofovir provides good results as adjuvant therapy after electrodessication and operative removal of CIN, PIN, VIN, and PAIN. ${ }^{48}$

\section{Interferons}

Interferons are endogenous intracellular proteins possessing not only antitumor, but also an antiviral immunomodulating effect. ${ }^{49,50}$ The application of interferon- $\alpha$ is already a standard therapy in a number of countries in Europe and the USA. Several studies have shown good results of systematic therapy with interferon in combination with a $\mathrm{CO}_{2}$ laser, surgical methods and electrodessication. ${ }^{49,50}$ The subcutaneous application of interferon- $\alpha-2 a$ and interferon- $\alpha-2 b$ within three cycles of one week each, at doses of 1-3 MIO I.U. is recommended as a good preoperative option. ${ }^{51}$ The intermission between each cycle lasts approximately 4 weeks. Its advantage compared to an intralesional application is the absence of pain and frequent visits to physicians. ${ }^{51}$ Handley ${ }^{52}$ and Eron ${ }^{53}$ each compare cryotherapy plus IFN injection versus cryotherapy plus placebo. Intralesional IFN $\alpha$ is injected directly into the base of each wart. The procedure is painful; local anesthesia is recommended to minimize discomfort. Data show no clear advantage of using subcutaneous interlesional interferon over cryotherapy alone. ${ }^{52,53}$

It is very interesting that Interferon does not have always a synergistic effect with other treatment modalities in the treatment of condyloma. ${ }^{54}$ Subcutaneous IFN $\alpha 2 a$ combined with cryotherapy was no more effective than cryotherapy alone in the treatment of primary anogential warts. ${ }^{55}$ Similarly, IFN $\alpha 2 a$ in combination with podophyllin was no more effective in the treatment of primary anogenital warts than 
podophyllin alone and is associated with more adverse events. ${ }^{52}$

However, combining Interferon with other treatments increases the likelihood of effective treatment. The additional application of subcutaneously administered interferon $\alpha-2 b$ to laser treated patients with chronic therapy-resistant genital lesions significantly enhanced the chance of eliminating these warts. ${ }^{56}$ There are also data that suggest a gel containing interferon can help treat vaginal warts. ${ }^{57}$

There are through backs due to the side effects of interferons, which are most frequently in form of sub-febrile temperatures, headache and faintness. ${ }^{51}$ Interferon- $\alpha$ in the form of a gel shows good compatibility. The application of this gel, containing 0.15 Mio I.U./g interferon- $\alpha$, to patients whose warts have been surgically removed was compared to the application of a placebo gel after one-month of use. The subsequent 24-month observation showed that $75 \%$ of the patients treated by the placebo gel had recurrences. Fifty-four percent of the patients treated by interferon gel also showed recurrences. The high percentage of the patients who have profited from the local application during the postoperative period is the basis for the more and more frequent application of this preparation. It is suggested that interferon is able to protect the basal keratinocytes from HPV infection, and the reason for this is likely due to its immunomodulating effect. ${ }^{36,49,50}$ The activation of Th- 1 cells and their cytotoxic effect is probably the basis of the effect. ${ }^{49-51}$

The combined systemic therapy of anogenital warts by interferon- $\alpha-2 a$ and isotretinoin (0,5-1 $\mathrm{mg} / \mathrm{kg} / \mathrm{d}$ ) has promising effects. ${ }^{58}$ Promising also are current results of single use PEG-IFN (pegylated interferon- $\alpha$ ) 80 microgram per week for 24 weeks, which led to full remission in HIV-positive patients at the stage of viremia. ${ }^{59}$ Interferon- $\alpha$ has probably an additional suppressive impact on viral replication with a synergetic effect added to the effect mediated by Tlymphocytes. ${ }^{59}$

\section{Problematic groups of patients and supplemen- tary therapeutic alternatives}

The fact that podophyllotoxin, interferon- $\alpha$, and imiquimod are contraindicated during pregnancy must be considered. ${ }^{4}$ Their side effects, such as intrauterine death and the appearance of different malformations (podophyllotoxin) are the basis of this contraindication. ${ }^{26}$ The application of highly concentrated (85\%) trichloracetic acid is a good therapeutic alternative during pregnancy. ${ }^{26}$ In case of strong pains and concerns of overdosing, rapid neutralization is possible with sodium bicarbonate. ${ }^{4}$

The second problematic group are children infected during birth by HPV-6, -11, and, in rarer occa- sions, by HPV-16, $-18,-31$, and -35 viral strains. ${ }^{4,26}$ The location of warts in the ano1genital area reveals the possibility of sexual abuse. ${ }^{13}$ Cryosurgery, electrodessication, and laser ablation under a short incubation narcosis are suitable options for this group of patients. ${ }^{13}$

Therapy of patients suffering from AIDS and transplant recipients is frequently difficult and not rarely ineffective. The reason is in the multifocal invasion of the lesions due to the weakened T-cell immunity. Because of this weakness, recurrences frequently arise. Surgical removal followed by prophylaxis with cidofovir/interferon gel provide promising results. ${ }^{48,60}$

\section{Invasive Therapeutic Methods Surgery}

One of the most reliable methods to remove single macular or plaque-like warts from the anogenital area is surgery. ${ }^{1}$ By using lidocaine-containing ointment with the application of infiltration anesthesia, the unhindered removal of the new formations is possible. ${ }^{1}$ Frequently, after a surgical intervention, recurrences in the peripheral areas of the removed warts are noticed, and this gives another meaning to the therapeutic intervention and leads to the application of new adjuvant methods. ${ }^{1}$

\section{Scalpel surgery}

Scalpel surgery of warts is not classified as an independent standard method. ${ }^{29}$ Some intra-epithelial neoplasias, such as Bowen's disease, bowenoid papulosis and Queyrat's erythroplasia, are an exception and need surgical removal and, occasionally, a primary closure of the operative wound edges. ${ }^{1,4,26,29}$ Circumcision in some cases provides good results. ${ }^{26,50}$

The primary therapy of bowenoid papulosis (i.e. PIN III and VIN III) is an exception, and also PAIN III in patients younger than 45 years of age, where electric cauterization and $\mathrm{CO}_{2}$ laser are more frequently applicable. ${ }^{26,61,62}$ Adjuvant 4-week application of interferon in the form of a gel 5 times a day, and also of cidofovir is necessary to reduce the risk of recurrences and provides good results. ${ }^{48,60}$

\section{Laser treatment}

However, laser treatment is more complex and costly than electrosurgery or cryotherapy. $\mathrm{A} \mathrm{CO}_{2}$ laser costs 10,000-50,000 and requires maintenance and additional training. Larger lesions with anogenital warts and some patients (children) may require general anesthesia. HPV DNA may be released during laser vaporization of genital HPV infected lesions; if appropriate evacuating equipment is used, contamination of the operator is unlikely. ${ }^{63,64}$ The surgeon must wear laser masks and use a vacuum ventilation system. ${ }^{65}$ 
Risk factors for transmission of genital warts by vaporization are the HPV type, thickness of the skin, and viral burden. ${ }^{65}$ A disadvantage of the lasers is that the risk of scarring is greater than of cryotherapy. There are no new significant studies comparing the benefit of carbon dioxide laser therapy versus placebo. In former studies, the efficacy of laser treatment ranged from 23 to 52 percent with 3-18 months follow up. Recurrence rates ranged from 60 to 77 percent. ${ }^{66}$ Newer studies either are poorly designed or involve too small a sample size. ${ }^{67}$ Most studies require additional therapies. ${ }^{65,68}$ Carrozza et al. compared extensive genital warts in HIV-positive and HIV-negative patients. The clearance and recurrence rates were similar for both groups. ${ }^{69}$

Good results are also achieved by removing the HPV-associated lesions by ERB YAG laser.

In some rare cases of inter-anal warts located closely to the linea dentata, some invasive methods have been described, such as loop colostomy. The purpose of these techniques is to minimize the contamination over the linea dentate. ${ }^{61}$

\section{Abrasion}

Abrasion and removal by scissors are widely applied in the cases of exophytic HPV-associated verrucous lesions in the peripheral and inguinal areas. ${ }^{29}$ The application of local anesthesia makes this method painless and easily accessible. Hemostasis is achieved by diathermy and wounds heal secondarily. Recurrences are very rare. ${ }^{29}$

\section{Cryosurgery}

Cryosurgery in genital warts leads to necrosis of the epidermis and occasionally of the superior part of the dermis; microthromboses in the blood vessels are often visualized histologically. ${ }^{26}$ The optimal course of this therapy requires the patient to be under control every week. Both spray (fast-flow) method and multiple application of a tampon soaked with nitrogen are used. Repetition of the cycles is quite possible and sometimes desirable and the determining or limiting factor in this case is the clinical picture. In the closedtype cryosystems, $\mathrm{CO}_{2}, \mathrm{~N}_{2} \mathrm{O}$, or $\mathrm{N}_{2}$ are used. These closed-type systems allow the multiple application of the catheter in the area of the anogenital warts, and this in a high rate of the cases guarantees a good therapeutic result. ${ }^{29}$ Cryosurgery has many advantages in some type of patients; the treatment is performed on an ambulatory basis, is easy, the method is accessible, and there are no serious complications. However, standardization of the different forms of cryosurgery is problematic. ${ }^{26,29}$ Recurrence of the warts according to some authors is possible in up to $75 \%$ of the cases. ${ }^{70}$ Other Trials show genital wart clearance rates from
79-88 percent with recurrences in $25-39$ percent despite multiple treatments. ${ }^{71-74}$

\section{Electric Surgery, Cauterization, Laser}

Electric surgery and laser therapy are the other invasive methods, finding wide application in the treatment of warts in the anogenital areas. ${ }^{28,60}$ Electric cauterization is an ideal method to remove big exophytic lesions (e.g. Buschke Löwenstein lesions), while $\mathrm{CO}_{2}$ laser is applicable to smaller lesions located on the verge of the transitional mucous membranes, for which the endophytic growth is characteristic (e.g. bowenoid papulosis). ${ }^{28}$ The most frequent, but not obligatory side effects of the above mentioned methods are depigmentation, hyperpigmentation, and cicatrisation. ${ }^{60}$ In the case of unilateral implementation of these two forms of invasive therapy, recurrences also reach $75 \%$. 25 For the surgical team, the presence of consequent ventilation systems and special face masks is very important to exclude, reduce, and minimize the risk of papillomatous alterations of the superior respiratory ducts of the operating room staff. ${ }^{16}$

Full remission without any side effects is achieved by FPDL (flash lamp-pumped pulsed dye laser), and this probably will make its application standard in the therapy of anogenital warts. ${ }^{75}$

There are no recent studies of electrosurgical methods for genital wart treatment. Some studies show a 61-94 percent clearance within 3-6 weeks of treatment. ${ }^{71}$ Despite their effectiveness, electrosurgery should be maybe considered as a second-line treatment.

Two randomized trials show slightly greater efficacy for electrotherapy compared with cryotherapy; however, the differences in outcome is only short term and does not persist after 3 months of followup. ${ }^{76,77}$

\section{Vaccination}

Papilloma viruses are difficulty reproduced under in vitro conditions, so generation of a "normal" vaccine is impossible. Thus, the generation of virus-like particles used in hepatitis B vaccination is interesting. The absolute reliability of this vaccination is derived from the fact that it does not contain infectious particles. Bi- and tetravalent vaccines exist, including 16 and 18 HPV types. The tetravalent vaccine contains viruslike particles of 6 and 11 types and, therefore, it additionally protects against condylomata accuminata.

The bivalent vaccine contains, in the form of adjuvant, not only aluminium salts, but also ASO4 (monophosphoryl lipid A). This ingredient is purposed to intensify the immune response. ASO4 is able to induce higher antibody titer levels, on one side, and on the other side, their longer persistence in patients' serum, in contrast to a similar vaccine, containing alu- 
minium salts only.

The recommendations concerning the vaccination applying bi- and tetravalent vaccines are approximately similar. Regarding the bivalent vaccine, triple intramuscular application per month 0 and 1 and 2 is recommended, and regarding the tetravalent vaccine 0,2 and 6 per month. The single vaccination dose contains $0,5 \mathrm{ml}$ or $20-40 \mu \mathrm{g}$ of antigen of the respective virus-like particles.

The tetravalent vaccination against HPV-6, -11, 16 and -18 (Gardasil $^{\mathrm{TM}}$ ) is the most popular one. Test analyses on 25,000 patients from 33 different countries have been performed and the results show significant reduction of the number of the precancerous cervical, vulvar and vaginal lesions due to the human papilloma viruses type 16 and $18 .^{78}$ The efficiency of this vaccine in the cases of condylomata accuminata infections due to papilloma virus strains -6 and -11 type is also proven. ${ }^{79}$ The application of Gardasil is able to prevent $70-80 \%$ of the patients from clinical manifestation of the highly differentiated cervical neoplasias. ${ }^{80}$

\section{Conclusions}

1) The different therapeutic methods must be applied in accordance with the clinical picture, taking into account the patient's general status, the presence of concomitant diseases, as well as the local and systematic compatibility of the side effects of each remedy.

2) A first-rank therapy of single lesions and/or in the case the patient refuses invasive methods to be applied, is considered to be the application of podophyllin toxin, imiquimod, cidofovir, or interferon.

3) The combined primary initial therapy aimed at the surgical removal of the lesions followed by the local application of Imiquimod or Interferon is considered to be the most efficient.

4) The early prevention by regular clinical control, information to the patient about the risk of transmission of certain "carcinoma forms" by sexual intercourse and the opportune vaccination, will probably lead to a drastic reduction of the cases of papilloma virus-associated anogenital warts. ${ }^{78}$

\section{Acknowledgements}

No sources of funding were used to assist in the preparation of this review. The author has no conflicts of interest that are directly relevant to the content of this review. 


\section{REFERÊNCIAS}

1. Scheinfeld N, Lehman DS. An evidence-based review of medical and surgical treatments of genital warts. Dermatol Online J. 2006;12:5.

2. Braun Falco O, Plewig G, Wolff HH. Dermatologie und Venerologie. 4th ed. Heidelberg: Springer Verlag Berlin; 1997. p.24-32.

3. Dupin N. Genital warts. Clin Dermatol. 2004;22:481-6.

4. Gross G. Condylomata acuminata und andere HPVassoziierte Krankheitsbilder des Genitale und der Harnröhre. Hautarzt. 2001;52:405-10.

5. Braun-Falco O, Plewig G, Wolff $\mathrm{HH}$, Burgdorf WHC, Landthaler M. Dermatologie und Venerologie. 5th ed. Heidelberg : Springer Verlag Berlin; 2005. p. 43-54.

6. Koutsky LA. Epidemiology of genital human papillomavirus infection. Epidemiol Rev 1988;10:122-63.

7. Koutsky LA. Epidemiology of genital human papillomavirus infection. Am J Med. 1997; 102(5A):3-8.

8. Oriel JD. Natural history of genital warts. Br J Vener Dis. 1971;47:1-13.

9. Wasef W, Sugunendran H, Alawattegama A. Genital warts in transsexual. Int J STD AIDS 2005; 16:388-9.

10. Feldman JG, Chirgwin K, Dehovitz JA, Minkoff H. The association of smoking and risk of condylomata acuminatum in women. Obstet Gynecol. 1997;89:346-50.

11. Kyriakis KP, Hadjivassiliou M, Paparizos VA, Riga P, Katsambas A. Determinants of genital wart case detection rates among STD clinic attendees in Athens, Greece. Int J Dermatol. 2005;44:650-3.

12. Kashima HK, Shah K. Recurrent respiratory papillomatosis. Clinical overview and management principles. Obstet Gynecol Clin North Am. 1987;14:581-8.

13. Ingram DL, Everett VD, Lyna PR, White ST, Rockwell LA. Epidemiology of adult sexually transmitted disease agents in children being evaluated for sexual abuse. Pediatr Infect Dis J. 1992;11:945-50.

14. Maw RD, Reitano M, Roy M. An international survey of patients with genital warts: perceptions regarding treatment and impact on lifestyle. Int $J$ STD AIDS. 1998;9:571-8.

15. von Krogh G, Gross G. Anogenital warts. Clin Dermatol. 1997; 15:355-68.

16. Von Krogh G, Gross G, Barrasso R. Warts and HPV-related squamous cell tumours of the genital area in adults. In: Gross G, von Krogh G, eds. Human papillomavirus infections in dermatovenereology. Boca-Raton: CRCPress, 1997. p. 259-304.

17. Demeter LM, Stoler MH, Bonez W, Corey L, Pappas P, Strussenberg $\mathrm{J}$, et al. Penile intraepithelial neoplasia clinical presentation and analysis physical state of human papillomavirus DNA. J Infect Dis. 1993;168:38-46.

18. Gross G, Ikenberg H, Gissmann L et al. Papillomavirus infection of the anogenital region: correlation between histology, clinical picture and virus type. Proposal of a new nomenclature. J Invest Dermatol. 1985;85:147-52.

19. Drake LA, Ceilley RI, Cornelison R, Dobes WL, Dorner W, Goltz RW, et al. Guidelines of care for warts: human papillomavirus. Committee on Guidelines of Care. J Am Acad Dermatol. 1995;32:98-103.

20. Barrasso R, Gross G. External genitalia: diagnosis. In:
Gross G, Barrasso R, eds. Human papilloma virus infection. A clinical atlas. Berlin: Ullstein-Mosby; 1997. p. 291-361.

21. Beutner KR, Tyring SK. Human papillomavirus and human disease. Am J Med. 1997;102:9-15.

22. Syrjänen K, Syrjänen S. Epidemiology of human papillomavirus infections and genital neoplasia. Scand J Infect Dis Suppl. 1990;69:7-17.

23. Syrjänen K. Long-term consequences of genital HPV infections in women. Ann Med. 1992;24:233-45.

24. O' Mahony C. Genital warts: current and future management options. Am J Clin Dermatol. 2005;6:239-43.

25. Beutner KR, Ferenczy A: Therapeutic approaches to genital warts. Am J Med 1997;102:28-37.

26. Gross G. Klinik und Therapie anogenitaler Warzen und papillomvirusassoziierter Krankheitsbilder. Hautarzt. 2001;52:6-17.

27. Snoeck R, Andrei G, De Clercq E. Specific therapies for human papilloma virus infections. Curr Opin Infect Dis. 1998;11:733-7.

28. Baker GE, Tyring SK. Therapeutic approaches to papillomavirus infections. Infect Dis Dermatol. 1997;15:331-40.

29. Gross G. Therapy of human papillomavirus infection and associated epithelial tumors. Intervirology. 1997; 40:368-77.

30. von Krogh G. Penile condylomata acuminate: an experimental model for evaluation of topical treatment with 0,5-1,0\% ethanolic preparations of podophyllotoxin for three days. Sex Transm Dis. 1981;8:179-84.

31. Peterson CS, Agner T, Ottevanger A, Larsen J, Ravnborg L. A single blind study of podophyllotoxin cream $0.5 \%$ and podophyllotoxin solution $0,5 \%$ in male patients with genital warts. Genitourin Med. 1995;71:391-2.

32. Ho GY, Bierman R, Beardsley L, Chang CJ, Burk RD. Natural history of cervicovaginal papillomavirus infection in young women. N Engl J Med. 1998;338:423-8.

33. 58. Lacey CJN, Goodall R, Tennvall GT, Maw R, Kinghorn GR, Fisk PG, et al. Randomised controlled trial and economic evaluation of podophyllotoxin solution, podophyllotoxin cream, and podophyllin in the treatment of genital warts. Sex Transm Infect. 2003;79:270-5.

34. 59. Claesson U, Lassus A, Happonen H, Hogstrom L, Siboulet A. Topical treatment of venereal warts: a comparative open study of podophyllotoxin cream versus solution. Int J STD AIDS. 1996;7:429-34.

35. Garland SM. Imiquimod. Curr Opin Infect Dis. $2003 ; 16: 85-9$.

36. Hengge UR, Cusini M. Topical immunomodulators for the treatment of external genital warts, cutaneous warts and molluscum contagiosum. Br J Dermatol. 2003; 149:15-9.

37. Edwards L, Ferenczy A, Eron L, Baker D, Owens ML, Fox TL, et al. Self-administered topical 5\% imiquimod cream for external anogenital warts. HPV Study Group. Human PapillomaVirus. Arch Dermatol. 1998;14:25-30.

38. Garland SM, Waddell R, Mindel A, Denham IM, McCloskey JC. An open -label phase II pilot study investigating the optimal duration of imiquimod 5\% cream for the treatment of external genital warts in women. Int J STD AIDS. 2006;17:448-52. 
39. Vexiau D, Decuypère L, Moyse D, Aractingi S. Efficacy and safety of 5\% imiquimod cream in external genital warts: a 6 month follow up evaluation. Ann Dermatol Venereol. 2005;132(Pt 1):845-51.

40. Yan J, Chen SL, Wang HN, Wu TX. Meta-analysis of 5\% imiquimod and $0,5 \%$ podophylotoxin in the treatment of condylomata acuminata. Dermatology. 2006; 213:218-23.

41. Moore RA, Edwards JE, Hopwood J, Hicks D. Imiquimod for the treatment of genital warts: a quantitative systematic review. BMC Infect Dis. 2001; 1:3.

42. Beutner KR, Spruance SL, Hougham AJ, Fox TL, Owens ML, Douglas JM Jr. Treatment of genital warts with an immune-response modifier (imiquimod). J Am Acad Dermatol. 1998;38:230-9.

43. Safrin S, Cherington J, Jaffe HS. Clinical uses of cidofovir. Revue Med Virol. 1997;7:145-56.

44. Zabawski EJ Jr, Cockerell CJ. Topical and intralesional cidofovir: a review of pharmacology and therapeutic effects. J Am Acad Dermatol 1998;39:741-5.

45. Naesens 1, Snoeck R, Andrei G, Balzarini J, Neyts J, De Clercq E. HPMPC (cidofovir), PMEA (adefovir) and related acyclic nucleoside phosphonate analogues: a review of their pharmacology and clinical potential in the treatment of viral infections. Antiviral Chem Chemother. 1997;8:1-23.

46. Calisto D, Arcangeli F. Topical cidofovir for condylomata acuminata of the genitalia in a -3-year-old child. J Am Acad Dermatol. 2003;49:1192-3

47. Martinelli C, Farese A, Mistro AD, Giorgini S, Ruffino I. Resolution of recurrent perianal condylomata acuminata by topical cidofovir in patients with HIV infection. J Eur Acad Dermatol Venereol. 2001;15:568-9.

48. Coremans G, Margaritis V, Snoeck R, Wyndaele J, De Clercq E, Geboes K. Topical cidofovir (HPMPC) is an effective adjuvant to surgical treatment of anogenital condylomata acuminata. Dis Colon Rectum. 2003;46:1103-8.

49. Cirelli R, Tyring S. Interferons in human papillomavirus infections. Antiviral Res. 1994;24:191-204.

50. Czelusta AJ, Evans T, Arany I, Tyring SK. A guide to immunotherapy of genital arts. Focus on interferon and imiquimod. BioDrugs. 1999;11:319-31.

51. Gross G, Roussaki A, Baur S, Wiegand M, Mescheder A. Systemically administered interferon alfa 2 a prevents reccurence of condylomata acuminate following $\mathrm{CO}_{2}$ laser ablation. The influence of the cyclic low-dose therapy regimen. Results of a placebo controlled clinical trial. Genitourin Med. 1996;72:71.

52. Handley JM, Horner T, Maw RD, Lawther H, Dinsmore WW. Subcutaneous interferon alpha 2 a combined with cryotherapy vs cryotherapy alone in the treatment of primary anogenital warts: a randomised observer blind placebo controlled study. Genitourin Med. 1991; 67:297-302.

53. Eron LJ, Alder MB, JM OR, Rittweger K, DePamphilis J, Pizzuti DJ. Recurrence of condylomata acuminata following cryotherapy is not prevented by systemically administered interferon. Genitourin Med. 1993;69:91-3.

54. Recurrent condylomata acuminata treated with recombinant interferon alpha-2a. A multicenter double-blind placebo-controlled clinical trial. Condylomata International Collaborative Study Group. Acta Derm Venereol. 1993;73:223-6.

55. Armstrong DK, Maw RD, Dinsmore WW, Morrison GD, Pattman RS, Watson PG, et al. A randomised, double-blind, parallel group study to compare subcutaneous interferon alpha-2a plus podophyllin with placebo plus podophyllin in the treatment of primary condylomata acuminata. Genitourin Med. 1994;70:389-93.

56. Petersen CS, Bjerring P, Larsen J, Blaakaer J, Hagdrup H, From E, et al. Systemic interferon alpha-2b increases the cure rate in laser treated patients with multiple persistent genital warts: a placebo-controlled study. Genitourin Med. 1991;67:99-102.

57. Syed TA, Ahmadpour OA. Human leukocyte derived interferon-alpha in a hydrophilic gel for the treatment of intravaginal warts in women: a placebo-controlled, double-blind study. Int J STD AIDS. 1998;9:769-72.

58. Yildirim M, Inaloz HS, Baysal V, Kesici D, Candir O. A case of condyloma acuminatum treated successfully with low -dose isotretinoin and interferon. Int J Clin Pract. 2004; 58:889-91.

59. Brockmeyer NH, Poffhoff A, Bader A, Hochdorfer B, Schlottmann R, Rasokat H, et al. Treatment of condylomata acuminata with pegylated interferon alfa-2b in HIVinfected patients. Eur J Med Res. 2006;11:27-32.

60. Gross G, Rogozinski T, Schöfer H, Jablonska S, Roussaki A, Wöhr C, et al. Recombinant interferon beta gel as an adjuvant in the treatment of recurrent genital warts: results of a placebo-controlled doubleblind study in 120 patients. Dermatology. 1998; 196: 330-4.

61. De Toma G, Cavallaro G, Bitonti A, Polistena A, Onesti MG, Scuderi N. Surgical management of perianal giant condyloma acuminatum (Buschke-Löwenstein tumor). Report of three cases. Eur Surg Res. 2006;38:418-22.

62. Ockenfels HM, Hammes S. [Laser treatments of warts.]. Hautarzt. 2008;59:116-23.

63. Garden JM, O'Banion MK, Shelnitz LS, Pinski KS, Bakus $\mathrm{AD}$, Reichmann ME, et al. Papillomavirus in the vapor of carbon dioxide laser-treated verrucae. JAMA. 1988;259:1199-202.

64. Ferenczy A, Behelak Y, Haber G, Wright TC Jr, Richart RM. Treating vaginal and external anogenital condylomas with electrosurgery vs CO2 laser ablation. J Gynecol Surg. 1995; 11:41-50.

65. Petersen CS, Bjerring P, Larsen J, Blaakaer J, Hagdrup H, From E, et al. Systemic interferon alpha-2b increases the cure rate in laser treated patients with multiple persistent genital warts: a placebo-controlled study. Genitourin Med. 1991;67:99-102.

66. Wiley DJ, Douglas J, Beutner K, Cox T, Fife K, Moscicki $\mathrm{AB}$, et al. External Genital Warts: Diagnosis, Treatment, and Prevention. Clin Infect Dis. 2002;35(Suppl 2):S210-24.

67. Duus BR, Philipsen T, Christensen JD, Lundvall F, Sondergaard J. Refractory condylomata acuminata: a controlled clinical trial of carbon dioxide laser versus conventional surgical treatment. Genitourin Med. 1985;61:59-61.

68. Davis BE, Noble MJ. Initial experience with combined 
interferon-alpha $2 \mathrm{~B}$ and carbon dioxide laser for the treatment of condylomata acuminata. J Urol. 1992;147:627-9.

69. Carrozza PM, Merlani GM, Burg G, Hafner J. CO(2) laser surgery for extensive, cauliflower-like anogenital condylomata acuminata: retrospective long-term study on 19 HIV-positive and 45 HIV-negative men. Dermatology. 2002;205:255-9.

70. Abdullah AN, Walzmann M, Wade A. Treatment of external genital warts comparing cryotherapy (liquid nitrogen) and trichloracetic acid. Sex Transm Dis. 1993;20:344-5.

71. Schoenfeld A, Ziv E, Levavi H, Samra Z, Ovadia J. Laser versus loop electrosurgical excision in vulvar condyloma for eradication of subclinical reservoir demonstrated by assay for 2'5' oligosynthetase human papillomavirus. Gynecol Obstet Invest. 1995;40:46-51.

72. Abdullah AN, Walzman M, Wade A. Treatment of external genital warts comparing cryotherapy (liquid nitrogen) and trichloroacetic acid. Sex Transm Dis. 1993;20:344-5.

73. Damstra RJ, van Vloten WA.Cryotherapy in the treatment of condylomata acuminata: a controlled study of 64 patients. J Dermatol Surg Oncol. 1991;17:273-6.

74. Godley MJ, Bradbeer CS, Gellan M, Thin RN. Cryotherapy compared with trichloroacetic acid in treating genital warts. Genitourin Med. 1987;63:390-2.

75. Komericki P, Akkilic M, Kopera D. Pulsed dye laser treatment of genital warts. Lasers Surg Med. 2006;38:273-6.

76. Stone KM, Becker TM, Hadgu A, Kraus SJ. Treatment of external genital warts: a randomised clinical trial comparing podophyllin, cryotherapy, and electrodesiccation. Genitourin Med. 1990;66:16-9.
77. Simmons PD, Langlet F, Thin RN. Cryotherapy versus electrocautery in the treatment of genital warts. $\mathrm{Br} \mathrm{J}$ Vener Dis. 1981;57:273-4.

78. Ansstasiou-Fotaki P, Deligeoroglou E, Kreatsas G. The GARDASIL vaccine can prevent cervical carcinoma caused by human papilloma virus (HPV) (results from our participation and from the study carried out in Greece). Akush Ginekol (Sofiia). 2007;46:17-20.

79. Petry KU. [What does HPV vaccination mean for gynaecologic cancer screening?] Hautarzt. 2007;58:501-6.

80. Brown RE, Breugelemans JG, Theodoratou D, Benard S. Costs of detection and treatment of cervical cancer, cervical dysplasia and genital warts in the UK. Curr Med Res Opin. 2006;22:663-70.

ENDEREÇO PARA CORRESPONDÊNCIA / MAILING ADDRESS: Georgi Tchernev Department of Dermatology, Venereology and Dermatosurgery VOP/MVZ Kirchbeim.

Steingaustrasse 13. 7230 Kirchbeim /Teck, Germany Email: georgi_tchernev@yaboo.de Tel./fax: $004970219300-220004970219300-221$

Como citar este artigo/How to cite this article: Tchernev G. Sexually transmitted papillomavirus infections: epidemiology, pathogenesis, clinic, morphology, important differential diagnostic aspects, current diagnostic and treatment options. An Bras Dermatol. 2009;84(4):377-89. 